\title{
A TECNOLOGIA EM SALA DE AULA: a favor de uma educação crítica.
}

\section{Dayana de O. Formiga, Jefferson Flores, Letícia M. Figueiredo, Sara Andrade, Tatiane M. Gomes.}

\begin{abstract}
Resumo
Este artigo tem como objetivo discutir o uso da tecnologia e analisar de que forma as TICs (Tecnologia da Informação e Comunicação) podem contribuir para um ensino crítico. A tecnologia tem tido um importante papel na vida das pessoas e muito tem se discutido sobre qual seria o papel das TICs na sala de aula. Nossa pesquisa, ainda em andamento, procura apontar os benefícios da tecnologia e defender o uso das TICs como recurso didático, pois consideramos que este recurso busca uma aproximação com o contexto social dos educandos. Desta maneira, tornase fundamental pensar de que forma as TICs podem ser transformadas em diferentes fontes de recursos para o processo de ensino-aprendizagem, ao mesmo tempo que deve repensar o excesso de aulas expositivas e inserir o aluno de forma ativa neste processo..
\end{abstract}

\section{Palavras-chave: \\ TICs, Metodologias, Ensino.}

\section{Introdução}

Ao falarmos sobre tecnologia na sala de aula há de se encarar vários dilemas, problemas com os quais os profissionais da área educacional se deparam cotidianamente. Por exemplo, de que forma as ferramentas tecnológicas podem auxiliar na educação se as mesmas são usadas para recreação e ociosidade de tempo no cotidiano dos alunos?

Obviamente que relacionar os métodos tecnológicos ao cotidiano educacional não é uma tarefa fácil, pelo contrário, pode se tornar um fardo e gerar resistência por parte dos professores ou até banalização por parte dos alunos. Desta forma, busca-se nesta pesquisa explorar as mais variadas metodologias que envolvem as TICS e utiliza-las para aumentar o rendimento no processo de ensino-aprendizagem.

\section{Resultados e Discussão}

A tecnologia vem ganhando espaço dentro das salas de aula, pois o seu papel não é o de apagar a educação tradicional, mas fazer com que os alunos cresçam mais em conhecimento e criticidade. A maior preocupação hoje tem sido em como mostrar uma pedagogia sem repetições, no qual o aluno deixa de ser apenas um mero reprodutor de conhecimento. Assim o objetivo é que os discentes se tornem autônomos, competentes e críticos.

Antes de introduzirmos a tecnologia de forma bemsucedida em nossas escolas, precisamos dar o primeiro passo, que é trabalhar a visão dos professores sobre as TICs, e convencê-los a repensar e quebrarem os preconceitos que muitos têm em relação ao seu. Assim, é necessário permitir que os alunos aprendam por si mesmos, deixando-os "livres" para o processo de ensinoaprendizagem, ao mesmo tempo em que os professores executam o acompanhamento e auxílio das atividades que envolvem as TICs. Os alunos devem ser despertados para elaborarem questionamentos e assim desenvolverem o pensamento crítico.

A tecnologia está presente em nosso cotidiano e inserida em nosso meio social e educativo. Vemos que hoje não há mais necessidade de passar horas em bibliotecas, pois muitos livros e enciclopédias estão disponíveis virtualmente e são de fácil acesso para aqueles que desejarem e precisarem lê-los. Torna-se fundamental que tais recursos e novas fontes sejam utilizados para facilitar o aprendizado. Precisamos mostrar aos alunos que eles podem aprender os conteúdos com ajuda dos smartphones, documentários e filmes, desde que esse recurso seja conduzido pelos professores. Há de se retomar estes conteúdos e abordagens, inserindo a análise crítica do docente. Desta forma, ao pedir para que os alunos façam trabalhos em casa, estes consigam pesquisar conteúdos e dados, e se sintam estimulados a criatividade e o senso de pesquisa, bem como a elaboração de resultados positivos que podem ser apresentados aos colegas e ao professor.

\section{Conclusões}

Ao se analisar todo o contexto aqui trabalhado, pode-se chegar à conclusão de que o uso da tecnologia em sala de aula é potencialmente benéfico para a educação. Diversas TICS podem ser utilizadas como metodologias de ensino, além de tornarem-se suportes relevantes na aplicação de muitos conteúdos.

Contudo ainda existe há uma grande resistência por parte de algumas escolas e profissionais, apegados ainda ao ensino tradicional e que não fazem o uso da tecnologia.

Há, portanto, um longo caminho ainda a ser percorrido até se alcançar um estado amplo de utilização da tecnologia, e os professores precisam se adaptar às novas metodologias de ensino, como as TICs, que estão inseridas no cotidiano dessa nova geração de discentes.

\section{Agradecimentos}

Agradecemos ao UNASP-EC e ao Programa PIBID/ CAPES pela ajuda e financiamento desta pesquisa.

ANDRADE, A. P. R. O Uso de Tecnologias na Educação: Computador e Internet. Monografia. Consórcio Setentrional de Educação. Universidade de Brasília e Universidade Estadual de Goiás. Brasília, DF, 2011.

CYSNEIROS, P. G.. Novas tecnologias na sala de aula: melhoria do ensino ou inovação conservadora? Informática Educativa, Bogotá, v. 12, n. 1, p.11-24, 1999.

TOSCHI, M. S. Série-Estudos - Periódico do Mestrado em Educação da UCDB. Campo Grande-MS, n. 19, p. 35-42, jan./jun. 2005. 